REVIEW ARTICLE

\title{
Review of the sequential development of Loma salmonae (Microsporidia) based on experimental infections of rainbow trout (Oncorhynchus mykiss) and Chinook salmon (O. tshawytscha)
}

\author{
Michael L. Kent ${ }^{1}$ and David J. Speare ${ }^{2}$ \\ ${ }^{1}$ Center for Fish Disease Research, Department of Microbiology, 220 Nash Hall, Oregon State University, Corvallis, Oregon \\ 97331-3404, USA; \\ ${ }^{2}$ Department of Pathology and Microbiology, Atlantic Veterinary College, University of Prince Edward Island, 1A 4P3, Canada
}

Key words: Microsporidia, Loma salmonae, rainbow trout, Chinook salmon, Oncorhynchus mykiss, Oncorhynchus tshawytscha

\begin{abstract}
Loma salmonae (Putz, Hoffman et Dunbar, 1965) is a common gill parasite of salmonids, and essentially all species in the genus Oncorhynchus are susceptible. Infections occur in both fresh and salt water. Loma salmonae is directly transmissible by ingestion of spores or infected tissue. The parasite infects the wall of blood vessels of various organs, but the gill is the primary site of infection. Initial infection occurs in the intestine, and xenomas are easily detected in the gills by standard histology at 4-6 wk post-exposure. A few presporogonic stages of the parasite are found in the heart endothelium prior to xenoma formation in the gills. Ultrastructure studies of early infections demonstrated that wandering blood cells transport the meronts to the gills, and that merogony occurs in pillar cells and other cells underlying the gill endothelium. Xenomas develop in these cells, resulting in hypertrophied host cells filled with spores. Xenomas ultimately rupture, and are associated with severe inflammation in which free spores are found in macrophages. The parasites are most pathogenic during this phase of the infection, resulting in severe vasculitis and clinical disease. Both rainbow trout (Oncorhynchus mykiss) and Chinook salmon (Oncorhynchus tshawytscha) recover from infections, but free spores persist in kidney and spleen phagocytes for many months after xenomas are absent in Chinook salmon. Fish that have recovered from the infection show strong immunity against the parasite, lasting up to 1 year. Fish are susceptible to infection by other routes of exposure by spores; co-habitation, anal gavage, and intramuscular, intraperitoneal and intravascular injection. Autoinfection probably occurs following release of spores in blood vessels after xenomas rupture. The optimal temperature for L. salmonae infections is $15-17^{\circ} \mathrm{C}$, with a permissive range of $11-20^{\circ} \mathrm{C}$.
\end{abstract}

Loma salmonae (Putz, Hoffman et Dunbar, 1965) is a common gill microsporidian of salmonid fishes, and essentially all species in the genus Oncorhynchus are susceptible (Shaw et al. 2000a). The infection is prevalent in wild and captive populations of salmon and trout (Wales and Wolf 1955, Bekhti and Bouix 1985, Kent et al. 1998, Shaw et al. 2000b), and disease associated with the infection has been reported in both freshwater (Markey et al. 1994, Bruno et al. 1995, Bader et al. 1998) and seawater (Speare et al. 1989, Kent et al. 1989, Kent and Poppe 1998). Most infections are reported from rainbow trout (Oncorhynchus mykiss) (Walbaum) and Chinook salmon (Oncorhynchus tshawytscha) (Walbaum), and our understanding of the development of the parasites is based mainly on laboratory studies with these species. Most infections were experimentally induced by either feeding infected tissues or purified spores. References to details of experimental methods are cited below. In general, the sequelae of infection are similar with both hosts, except that Chinook are more susceptible (Shaw et al. 2000b, Ramsay et al. 2002) and they remain infected longer (Kent et al. 1999).

\section{SEQUENTIAL DEVELOPMENT}

The following is a description of the sequential development of the parasite based on our observations from per os laboratory infections with either rainbow trout in freshwater and Chinook salmon held in seawater. Host differences are noted where appropriate.

The gut is the initial site of infection (Shaw et al. 1998, Sánchez et al. 2001a). Fish can be experimentally infected per os by intubation of spores (Shaw et al. 1998), infected tissue (Kent et al. 1995, 1999, Speare et al. 1998a, b) or by co-habitation (Shaw et al. 1998, Ramsay et al. 2003). Hauck (1984) suggested infection might occur by direct uptake of spores by phagocytic cells within the gills. However, placement of infectious spores directly on gills of Chinook did not result in infection (Shaw et al. 1998).

This paper was presented at the NATO Advanced Research Workshop "Emergent Pathogens in the 21st Century: First United Workshop on Microsporidia from Invertebrate and Vertebrate Hosts", held in České Budějovice, Czech Republic, July 12-15, 2004. 
Shaw et al. (1998) found spores and possible sporoplasms in the intestinal epithelium shortly after exposure by standard histology. Sánchez et al. (2001a) further confirmed this observation and found the parasite in epithelial cells and the lamina propria of the small intestine as early as $12 \mathrm{~h}$ post-exposure (p.e.) by using a Loma-specific in situ hybridisation (ISH) probe (Fig. 1). The parasite is likely transported from the gut in leucocytes (Rodríguez-Tovar et al. 2002), and early merogonic stages have been observed by ISH (Sánchez et al. 2001a) or PCR (Sánchez et al. 2000) in the heart endocardium a few days after infection. Loma salmonae is first detected in the gills about 2-3 wk p.e. (Sánchez et al. 1999, 2001a, Rodríguez-Tovar et al. 2002). In the gills, initially meronts are found within cells underlying the endothelium (Fig. 4) or within pillar cells of blood vessels (Rodríguez-Tovar et al. 2002). The pillar cells are probably secondarily infected by phagocytizing infected leucocytes. Sporogony and xenoma development follows in the cells underlying the endothelium, and spores are first detected around 4 wk p.e. (RodríguezTovar et al. 2003). Spores are peripherally located in the xenomas. Xenomas often contain multiple host cell nuclei (Fig. 3), reach a size of about $0.5 \mathrm{~mm}$, and are found in both the secondary lamellae and deep within primary vasculature of the gills. Xenomas are occasionally seen in other organs, including the heart, spleen, kidney and pseudobranch (Kent et al. 1989). Inflammation associated with xenomas is observed at around 6 wk p.e. Many xenomas ultimately rupture, and this is followed by severe, focal, chronic perivasculitis in which numerous spores are found within phagocytes (Fig. 4) (Speare et al. 1998a, Kent et al. 1995). In addition to large numbers of phagocytes, the perivascular lesions often contain abundant eosinophilic debris, identified as fibrin (Kent et al. 1995). This suggests severe damage to blood vessel walls and activation of Factor XII.

\section{AUTOINFECTION}

Autoinfection probably occurs by spores released from ruptured xenomas being transported to other tissues and forming new xenomas. Rodríguez-Tovar et al. (2003) present ultrastructural evidence for autoinfection with Loma morhua. Although not direct proof, autoinfection with $L$. salmonae was indicated by inducing xenomas in fish following intravascular injection of purified spores (Shaw et al. 1998).

\section{RECOVERY}

Rainbow trout recover from the infection (based on reduction and ultimate disappearance of xenomas) between 10-14 wk p.e (Speare et al. 1998a, b). The infection is more severe in Chinook salmon (Ramsay et al. 2002, Shaw et al. 2000a). Xenomas are still prevalent at $14 \mathrm{wk}$ p.e., and we have detected xenomas up to $21 \mathrm{wk}$ p.e. with this species (Kent et al. 1999). We have also found that free spores within the kidney interstitium persist for many months after xenomas have resolved (Kent et al. 1999).

\section{OTHER ROUTES OF INFECTION}

Shaw et al. (1998) showed that fish could also be infected by co-habitation, anal gavage, and intramuscular, intraperitoneal and intravascular injection of spores. The onset of xenoma formation and clearance of xenomas is delayed in fish infected by natural co-habitation compared to per os infection (Ramsay et al. 2003). Becker and Speare (2004a) showed that L. salmonae is transmissible from live infected fish in water without direct contact with recipient fish.

We have observed a high prevalence of $L$. salmonae in the ovaries of sexually mature Chinook salmon (Fig. 2) (Docker et al. 1997), which suggested that transovarial (vertical) transmission to progeny may occur. Transmission of microsporidia from one generation to the next with eggs or sexual products has also been suggested for Pseudoloma neurophilia (cf. Kent and Bishop-Stewart 2003) and Pleistophora ovariae (cf. Summerfelt 1972). Although confirmed with insect microsporidia (Dunn et al. 2001), true vertical transmission (i.e., transmission of the infection to embryos within eggs) for these fish microsporidia has not been confirmed - i.e., perhaps the infection is spread to progeny with sexual products, rather than directly within eggs. Shaw et al. (1999) have found that the spores of $L$. salmonae can survive iodine treatment at $100 \mathrm{ppm}$ for $15 \mathrm{~min}$, a dose typically used for disinfecting salmonid eggs after spawning. This indicates that spores of $L$. salmonae could easily survive in ovarian fluid following this treatment, and thus would be a risk to fry from infected adults.

\section{RESISTANCE}

Salmonids that have recovered from the infection exhibit strong resistance to re-infection (Speare et al. 1998b, Kent et al. 1999). Sánchez et al. (2001c) discovered a strain of Loma salmonae that causes heavy infection in brook trout (Salvelinus fontinalis), but shows very low virulence to rainbow trout. Infection of rainbow trout with this low-virulence strain (L. salmonae $\mathrm{SV}$ ) also induces strong protection to re-infection by a virulent strain (Sánchez et al. 2001b, c). In addition, rainbow trout infected outside the optimal temperature range for xenoma formation (which is $10-19^{\circ} \mathrm{C}$ ) also are protected to re-infection (Beaman et al. 1999). We have found that Chinook salmon can maintain this resistance for up to one year, providing encouragement for vaccine development.

\section{PATTERNS OF DISEASE}

Morbidity and mortality due to L. salmonae infections in fish reared in freshwater is usually associated 

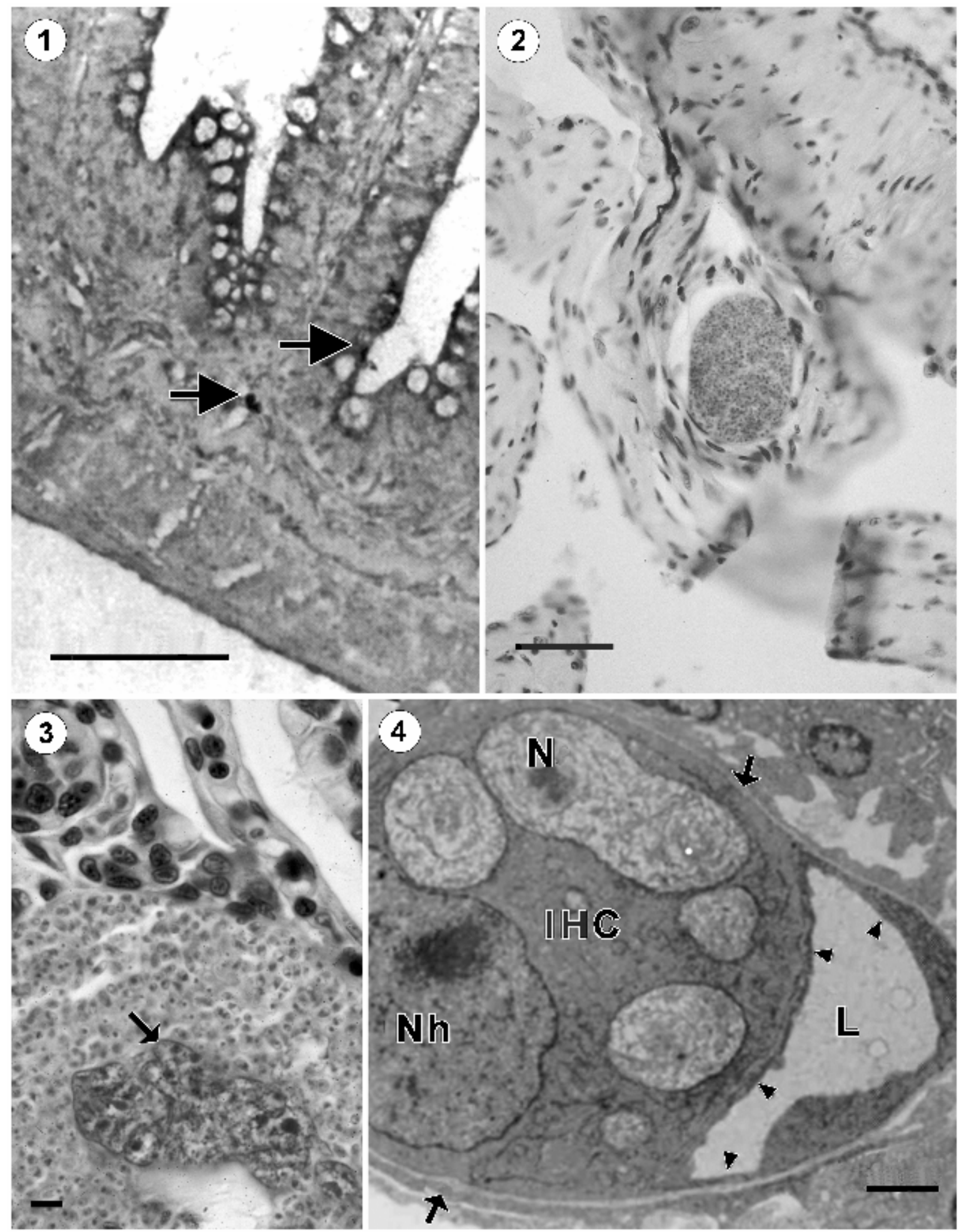

Fig. 1. Small intestine of rainbow trout Oncorhynchus mykiss infected with Loma salmonae, 12 hours post exposure. Early stages of infection (meronts?) are in the lamina propria (arrows). In situ hybridisation with Loma salmonae ssDNA - DIG-labeled probe and AP conjugated anti-DIG Fab fragments, methyl green counter stain. Fig. 2. Loma salmonae xenoma in blood vessel in ovary of sexually mature Chinook salmon Oncorhynchus tshawytscha. Haematoxylin and eosin. Fig. 3. Intact xenomas of Loma salmonae in Chinook salmon $O$. tshawytscha. Note absence of tissue reaction at xenoma wall and multiple host cell nuclei (arrow). Haematoxylin and eosin. Fig. 4. Transmission electron micrograph of meronts of Loma salmonae within host cell underlying the capillary endothelium in gills of rainbow trout O. mykiss. IHC - infected host cell; $\mathrm{N}$ - parasite nucleus; $\mathrm{Nh}$ - host cell nucleus; L - capillary lumen; arrows - basement membrane; arrowheads - flanges of adjacent pillar cells. Scale bars: Figs. 1, $2=100 \mu \mathrm{m}$; Fig. $3=10 \mu \mathrm{m}$; Fig. $4=1 \mu \mathrm{m}$. (Fig. 1 reprinted with permission from Sánchez et al. 2001a.) 


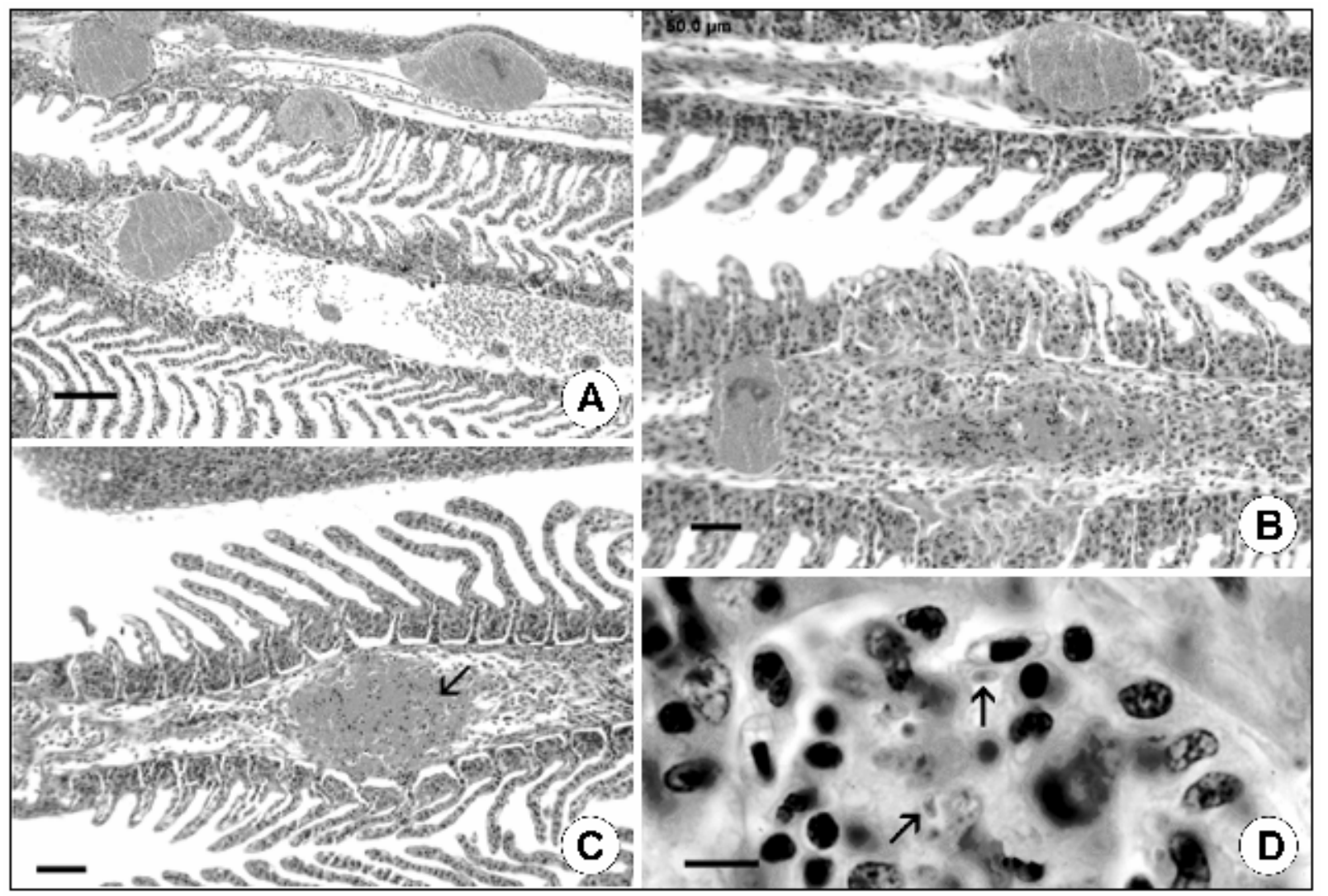

Fig. 5. Gill of a Chinook salmon Oncorhynchus tshawytscha from netpen with clinical Loma salmonae infection. Haematoxylin and eosin. A - Multiple, intact xenomas in the primary blood vessels and gill lamellae. B-D - Severe branchitis in following degeneration of xenomas. B - Low magnification showing chronic, mononuclear inflammation in gill filament with adjacent focal epithelial hyperplasia. C - Eosinophilic debris (arrow) rich in fibrin in gill filament. D - High magnification showing spores (arrows) in granulomatous matrix in perivasculature of gill filament. Scale bars: $\mathrm{A}-\mathrm{C}=50 \mu \mathrm{m} ; \mathrm{D}=10 \mu \mathrm{m}$.

with numerous intact xenomas replacing gill tissue (Bruno et al. 1995). However, severe systemic disease was seen in one epizootic in freshwater-reared Chinook salmon (Hauck 1984). Marine farming of salmonids has increased rapidly over the last two decades, and concurrent with the growth of this industry the parasite has been recognized as a problem for coho salmon (Oncorhynchus kisutch) and Chinook salmon reared in seawater netpens. The severe inflammatory lesions associated with ruptured xenomas is a common histopathological finding in fish with clinical disease from netpens (Kent et al. 1989, Speare et al 1989).

\section{TEMPERATURE EFFECTS}

Water temperature is a key regulator of the life cycle of L. salmonae, with rates of development increasing through the permissive temperature range of $11-20^{\circ} \mathrm{C}$ (Beaman et al. 1999). Temperatures outside of this range are not permissive to the parasite, although, colder water can be permissive to the parasite so long as the early stages of the life cycle have already been completed (Speare et al. 1999). The optimal temperature for L. salmonae is $15-17^{\circ} \mathrm{C}$ (Beaman et al. 1999). Recently, it has also been shown that temperature regulates the rate of clearance of xenomas (Becker and Speare 2004b), which provides an interesting avenue through which to explore non-pharmacological methods of treatment.

\section{VIABILITY OF SPORES IN WATER}

Shaw et al. (2000b) investigated the viability of $L$. salmonae spores under laboratory conditions by polar filament extrusion and infectivity to Chinook salmon. Extrusion rates of isolated spores decreased from about $50 \%$ to zero by $100 \mathrm{~d}$ after storage in freshwater or seawater at $4^{\circ} \mathrm{C}$. However, spores stored up to $95 \mathrm{~d}$ in either condition were infectious to Chinook salmon. 


\section{REFERENCES}

BADER J.A., SHOTTS E.B., STEFFENS W.L., LOM J. 1998: Occurrence of Loma cf. salmonae in brook, brown and rainbow trout from Buford Trout Hatchery, Georgia, USA. Dis. Aquat. Org. 34: 211-216.

BEAMAN H.J., SPEARE D.J., BRIMACOMBE M. 1999: Regulatory effects of water temperature on Loma salmonae (Microspora) development in rainbow trout. J. Aquat. Anim. Health 11: 237-245.

BECKER J.A., SPEARE D.J. 2004a: Ultraviolet light control of horizontal transmission of Loma salmonae. J. Fish Dis. 27: $177-180$

BECKER J.A., SPEARE D.J. 2004b: Impact of water temperature shift on xenoma clearance and recovery time during a Loma salmonae (Microsporidia) infection in rainbow trout Oncorhynchus mykiss. Dis. Aquat. Org. 58: 185-191.

BEKHTI M., BOUIX G. 1985: Loma salmonae (Putz, Hoffman et Dunbar, 1965) et Loma diplodae n. sp., microsporidies parasites de branchies de poissons téléostéens: implantation et données ultrastructurales. Protistologica 21: 47-59.

BRUNO D.W., COLLINS R.O., MORRISON C.M. 1995: The occurrence of Loma salmonae (Protozoa: Microspora) in farmed rainbow trout, Oncorhynchus mykiss Walbaum, in Scotland. Aquaculture 133: 341-344.

DOCKER M.F., DEVLIN R.H., RICHARD J., KHATTRA J., KENT M.L. 1997: Sensitive and specific polymerase chain reaction assay for detection of Loma salmonae (Microsporea). Dis. Aquat. Org. 29: 41-48.

DUNN A.M., TERRY R.S., SMITH J.E. 2001: Transovarial transmission in the Microsporidia. Adv. Parasitol. 48: 57100.

HAUCK A.K. 1984: A mortality and associated tissue reactions of chinook salmon, Oncorhynchus tshawytscha (Walbaum), caused by the microsporidian Loma sp. J. Fish Dis. 7: 217-229.

KENT M.L., BISHOP-STEWART J.K. 2003: Transmission and tissue distribution of Pseudoloma neurophilia (Microsporidia) of zebrafish Danio rerio. J. Fish Dis. 26: 1-4.

KENT M.L., DAWE S.C., SPEARE D.J. 1995: Transmission of Loma salmonae (Microsporea) to chinook salmon in sea water. Can. Vet. J. 36: 98-101.

KENT M.L., DAWE S.C., SPEARE D.J. 1999: Resistance to reinfection in chinook salmon (Oncorhynchus tshawytscha) to Loma salmonae (Microsporidia). Dis. Aquat. Org. 37: 205-208.

KENT M.L., ELLIOTT D.G., GROFF J.M., HEDRICK R.P. 1989: Loma salmonae (Protozoa: Microspora) infections in seawater reared coho salmon, Oncorhynchus kisutch. Aquaculture 80: 211-222.

KENT M.L., POPPE T.T. 1998: Diseases of Seawater Netpenreared Salmonids. Pacific Biological Station Press, Nanaimo, British Columbia, Canada, 138 pp.

KENT M.L., TRAXLER G.S., KIESER D., RICHARD J., DAWE S.C., SHAW R.W., PROSPERI-PORTA G., KETCHESON J., EVELYN T.P.T. 1998: Survey of salmonid pathogens in ocean-caught fishes in British Columbia, Canada. J. Aquat. Anim. Health 10: 211-219.
MARKEY P.T., BLAZER V.S., EWING M.S., KOCAN K.M. 1994: Loma sp. in salmonids from the eastern United States: associated lesions in rainbow trout. J. Aquat. Anim. Health 6: 318-328.

RAMSAY J.M., SPEARE D.J., BECKER J.A., DALEY J. 2003: Loma salmonae-associated xenomas onset and clearance in rainbow trout, Oncorhynchus mykiss (Walbaum): comparisons of per os and cohabitation exposure using survival analysis. Aquacult. Res. 34: 1329-1335.

RAMSAY J.M., SPEARE D.J., DAWE S.C., KENT M.L. 2002: Xenoma formation during microsporidial gill disease of salmonids caused by Loma salmonae is affected by host species (Oncorhynchus tshawytscha, O. kisutch, O. mykiss) but not by salinity. Dis. Aquat. Org. 11: 125-131.

RODRÍGUES-TOVAR L.E., WADOWSKA D.W., WRIGHT G.M., GROMAN D.B., SPEARE D.J., WHELAN D.S. 2003: Ultrastructural evidence of autoinfection in the gills of Atlantic cod Gadus morhua infected with Loma sp. (phylum Microsporidia). Dis. Aquat. Org. 57: 227-230.

RODRÍGUES-TOVAR L.E., WRIGHT G.M., WADOWSKA D.W., SPEARE D.J., MARKHAM R.J.F. 2002: Ultrastructure study of the early development and localization of Loma salmonae in the gills of experimentally infected rainbow trout. J. Parasitol. 88: 244-253.

SÁNCHEZ J.G., SPEARE D.J., MARKHAM R.J.F. 1999: Nonisotopic detection of Loma salmonae (Microspora) in rainbow trout (Oncorhynchus mykiss) gills by in situ hybridization. Vet. Pathol. 36: 610-612.

SÁNCHEZ J.G., SPEARE D.J., MARKHAM R.J.F. 2000: Normal and aberrant tissue distribution of Loma salmonae (Microspora) within rainbow trout, Oncorhynchus mykiss (Walbaum), following experimental infection at water temperatures within and outside of the xenoma-expression temperature boundaries. J. Fish Dis. 23: 235-242.

SÁNCHEZ J.G., SPEARE D.J., MARKHAM R.J.F., JONES S.R. 2001b: Experimental vaccination of rainbow trout against Loma salmonae using a live low-virulence variant of L. salmonae. J. Fish Biol. 59: 442-448.

SÁNCHEZ J.G., SPEARE D.J., MARKHAM R.J.F, JONES S.R.M. 2001c: Isolation of a Loma salmonae variant: biological characteristics and host range. J. Fish Biol. 59: 427-441.

SÁNCHEZ J.G., SPEARE D.J., MARKHAM R.J.F., WRIGHT G.B., KIBENGE F.S.B. 2001a: Localization of the initial developmental stages of Loma salmonae in rainbow trout (Oncorhynchus mykiss). Vet. Pathol. 38: 540-546.

SHAW R.W., KENT M.L. 1999: Fish microsporidia. In: M. Wittner and L.M. Weiss (Eds.), The Microsporidia and Microsporidiosis. ASM Press, Washington, D.C., pp. 418446.

SHAW R.W., KENT M.L., ADAMSON M.L. 1998: Modes of transmission of Loma salmonae (Microsporidia). Dis. Aquat. Org. 33: 151-156.

SHAW R.W., KENT M.L., ADAMSON M.L. 1999: Iodophor treatment is not completely efficacious in preventing Loma salmonae (Microsporidia) transmission in experi- 
mentally challenged chinook salmon, Oncorhynchus tshawytscha (Walbaum). J. Fish Dis. 22: 311-313.

SHAW R.W., KENT M.L., ADAMSON M.L. 2000b: Viability of Loma salmonae (Microsporidia) under laboratory conditions. Parasitol. Res. 86: 978-981.

SHAW R.W., KENT M.L., BROWN A.M.V., WHIPPS C.M., ADAMSON M.L. 2000a: Experimental and natural host specificity of Loma salmonae (Microsporidia). Dis. Aquat. Org. 40: 131-136.

SHAW R.W., KENT M.L., DOCKER M.F., BROWN A.M.V., DEVLIN R.H., ADAMSON M.L. 1997: A new species of Loma (Microsporea) in shiner perch (Cymatogaster aggregata). J. Parasitol. 83: 296-301.

SPEARE D.J., ARSENAULT G.J., BUOTE M.A. 1998a: Evaluation of rainbow trout as a model for use in studies on pathogenesis of the branchial microsporidian Loma salmonae. Contemp. Top. Lab. Anim. Sci. 37: 55-58.

Received 13 September 2004
SPEARE D.J., BEAMAN H.J., DALEY J. 1999: Effect of water temperature manipulation on a thermal unit predictive model for Loma salmonae. J. Fish Dis. 22: 277-283.

SPEARE D.J., BEAMAN H.J., JONES S.R.M., MARKHAM R.J.F., ARSENAULT G.J. 1998b: Induced resistance in rainbow trout, Oncorhynchus mykiss (Walbaum), to gill disease associated with the microsporidian gill parasite Loma salmonae. J. Fish Dis. 21: 93-100.

SPEARE D.J., BRACKETT J., FERGUSON H.W. 1989: Sequential pathology of the gills of coho salmon with a combined diatom and microsporidian gill infection. Can. Vet. J. 30: 571-575.

SUMMERFELT R.C. 1972: Studies on the transmission of Pleistophora ovariae, the ovary parasite of the golden shiner (Notemigonus crysoleucas). In: Final Report, Project No. 4-66-R. Natl. Mar. Fish. Serv., pp. 1-19.

WALES J., WOLF H. 1955: Three protozoan diseases of trout in California. Calif. Fish Game 41: 183-187.

Accepted 12 January 2005 